\title{
Science and surmise
}

\author{
Marcello Lotti
}

Published online: 3 September 2009

(C) Springer-Verlag 2009

An analysis of scrotal asymmetry in ancient greek and roman sculptures revealed that although the ancient artists were correct in tending to place the right testicle higher, they were wrong in so far as they also tended to make the lower testicle the larger. Because the weight of the testicles was seen as a crucial part of their physiological function, it is hardly surprising that the lower testicle the one that had pulled down further, also had to be the heavier (McManus 1976, 2004). Simple mechanics but, unfortunately, incorrect biology. Is the process of risk assessment falling into similar presumption mistakes? How much inference and science combine in risk assessment? Risk assessment derives from a braiding between science and assertion of values leading to trade-offs between incomplete understanding of toxicities and need of intervention (The Royal Society 1992). However, the possibilities of intervention and control may change and are to be continuously balanced against the expansion of scientific knowledge.

The food scare of some years ago related to the dye Sudan I illustrates the need for a better frame of reference in risk characterization. Equivocal experimental data suggest that Sudan I is a carcinogen, and it was classified in class 3 by both the International Agency on Research on Cancer and the European Union. Since 1995, it was banned in the European Union as a food additive. When several food products derived from batches of hot pepper contaminated with this dye were found, the European Commission

M. Lotti $(\bowtie)$

Dipartimento di Medicina Ambientale e Sanita' Pubblica,

Universita' degli Studi di Padova, Via Giustiniani 2,

35128 Padova, Italy

e-mail: marcello.lotti@unipd.it took emergency measures to withdraw these products because of "the seriousness of the health threat" (The Official Journal of the European Union 2003). The scandal soared, the Government of Sudan was outraged because a cancer-causing dye was named after the African country and its ambassador wrote to the Food Standards Agency of United Kingdom asking it to change the name of Sudan I to prevent further harm to Sudan's reputation. However, looking at carcinogenic doses in rodents of Sudan I (NTP 1982) and of capsaicin, the natural constituent of hot peppers (Gold et al. 2001), and at their average possible consumption in humans, the risk of eating the products containing the former was at least one order of magnitude lower than that of the latter. Not to see the beam in one's own eye.

Whereas it is clear that any carcinogen cannot be portrayed in the same way, we also must now confront with and capitalize the recent spectacular achievements of biomedical sciences. Maintaining cancer as the example, research has shown that in the development of disease the influence of the environment and that of genes interact in a cooperative way. They work upon each other in an indispensable way, and microarray technology is now trying to dissect genes that modify their expression as a reaction to chemicals, from those reacting to the disease and from those inducing the disease itself. The understanding of such interactions will be of paramount importance in the assessment of carcinogenic risks. Promising strategies for the risk assessment of cancer should take advantage from the fact that the molecular characterization of cancers involves aspects to which toxicology may contribute. These may include inputs to the Cancer Genome Atlas, a repertoire of oncogenic mutations (http://cancergenome.nih.gov/index.asp.), and to the understanding of mutagenic hierarchies, i.e. the relative importance of multiple mutations of oncogenes in maintaining cancer cell vitality (Varmus 2006), of epigenetic factors 
(Jones and Baylin 2002), of miRNA functions (Krützfeldt et al. 2006), and of others. Moreover, because characteristics of cancer cells are acquired with different strategies and time-frames (Hanan and Weinberg 2000), the detection of early changes induced by chemicals represents the unrivalled challenge in the assessment of carcinogenetic risk. For instance, genetic instability of cancer cells is selected for early in tumour development because only these cells can acquire the multiple additional changes that are necessary to become malignant (Vogelstein and Kinzler 2004). Though some mechanisms causing instability are known (Maser and DePinho 2002; Aguilera and Gómez-González 2008; Williams et al. 2008), toxicological research has the tools to decipher more, leading to a better assessment of the carcinogenicity potential for a variety of chemicals.

It is increasingly clear that many forms of toxicity involve a handful of evolutionarily conserved responses to injury. Therefore, the understanding of certain stereotypical fundamental reactions will help to identify the risks posed by chemicals. Years ago, a "matrix" approach to the prediction of health risks was proposed using information derived from commonality between disease states that are not induced by chemicals and those elicited by toxicants, and the differences between exposed and unexposed individuals (Lotti and Nicotera 2002). Meanwhile, a reference collection of gene-expression profiles has been recently created to find connections among molecules sharing a mechanism of action, chemical and physiological processes, and diseases and drugs (Lamb et al. 2006).

The present-day scenario is characterized by some public distrust in the ability to predict risks and by the ongoing revolutionary discoveries in biomedical sciences. Therefore, higher priorities in risk assessment should be given to offering a sound perspective to the inevitable mistakes and approximations and to taking advantage from biomedical research in order to go deeper into detailed mechanisms of toxicities. Thus, having toxicological research incorporated into the mainstream of fundamental biomedical research, both a meaningful hazard identification and a contribution to the development of basic knowledge will be derived.

Toxicologists have their own opinion about the procedures of risk assessment, and they might judge whether the goals of science and prevention, as well as of a much murkier ideal of "progress" are balanced against one other. Indeed, the position to which I have been led in this note is not a comfortable one. It is likely to inspire the charge, from detractors, that my suggestion to better introduce ourselves into mainstream biomedical sciences is not focussed and impractical and the accusation, from boosters, that science is too precious and too important to flirt with practical forecasts. To the formers, I can only offer the invitation to reflect on the limits of simplification and of certain conclusions of risk assessment. To the latter, it is worth pointing out that it would be curious to insist that science is for the benefit of mankind and simultaneously defending their isolation from practical issues.

\section{References}

Aguilera A, Gómez-González B (2008) Genome instability: a mechanistic view of its causes and consequences. Nature Rev Genetics 9:204-217. doi:10.1038/nrg2268

Gold LS, Slone TH, Ames BN, Manley NB (2001) Pesticides residues in food and cancer risk: a critical analysis. In: Krieger RI (ed) Handbook of Pesticide Toxicology, vol 1. Academic Press, San Diego, CA, pp 799-843

Hanan D, Weinberg RA (2000) The hallmarks of cancer. Cell 100:57-70

Jones PA, Baylin SB (2002) The fundamental role of epigenetic events in cancer. Nature Rev Genetics 3:415-428. doi:10.1038/nrg816

Krützfeldt J, Poy MN, Stoffel M (2006) Strategies to determine the biological function of microRNAs. Nat Genet 38:S14-S19. doi: $10.1038 / \mathrm{ng} 1799$

Lamb J, Crawford ED, Peck D, Modell JW, Blat IC, Wrobel MJ, Lerner J, Brunet JP, Subramanian A, Ross KN, Reich M, Hieronymus H, Wei G, Amstrong SA, Haggarty SJ, Clemons PA, Wei R, Carr SA, Lander ES, Golub TR (2006) The connectivity map: using gene-expression signatures to connect small molecules, genes and disease. Science 313:1929-1935. doi:10.1126/ science.1132939

Lotti M, Nicotera P (2002) A risky business. Nature 416:481. doi: 10.1038/416481a

Maser RS, DePinho RA (2002) Connecting chromosomes, crisis, and cancer. Science 297:565-569

McManus IC (1976) Scrotal asymmetry in man and in ancient sculpture. Nature 259:426

McManus IC (2004) Right-left and the scrotum in greek sculpture. Laterality 9:189-199

NTP (1982) National Toxicology Program pub.no. 82-1782

The Official Journal of the European Union (2003) publication L154/114

The Royal Society (1992) Risk: analysis, perception and management. The Royal Society, London

Varmus H (2006) The new era in cancer research. Science 312:11621165. doi: $10.1126 /$ science. 1126758

Vogelstein B, Kinzler KW (2004) Cancer genes and the pathways they control. Nature Med 10:789-799. doi:10.1038/nm1087

Williams BR, Prabhu VR, Hunter KE, Glazier CM, Whittaker CA, Housman DE, Amon A (2008) Aneuploidy affects proliferation and spontaneous immortalization in mammalian cells. Science 322:703-709. doi:101126/science. 1160058 